\title{
Non-standard Employment in Sweden
}

\author{
Per Skedinger ${ }^{1,2}$ (D)
}

\begin{abstract}
In Sweden, as in many other countries, marginal groups tend to be overrepresented in non-standard employment. A decomposition of the employment rate of full-time workers on permanent contracts reveals that non-standard employment contributes to a substantially weaker labour market attachment for females and the foreign born than suggested by conventional employment figures alone. Our econometric analysis shows that the negative wage premia associated with fixed-term employment are considerably smaller in Sweden, both for natives and foreign born, than those that have been found for other countries. This may be due to a highly compressed wage structure and extensive coverage of collective bargaining in Sweden. On the whole, the type of fixed-term contract seems not to matter for the estimated wage premia.
\end{abstract}

Keywords Fixed-term employment · Part-time employment · Labour market attachment . Wage differentials

JEL Classification $\mathrm{J} 21 \cdot \mathrm{J} 31$

Thanks to Simon Ek and two anonymous referees for valuable comments and to Simon Ek and Charlotta Olofsson for expert research assistance. Financial support from the Johan and Jakob Söderberg

Foundation, the Marianne and Marcus Wallenberg Foundation and the Jan Wallander and Tom Hedelius Foundation is gratefully acknowledged.

$凶 \quad$ Per Skedinger

per.skedinger@ifn.se

1 Research Institute of Industrial Economics (IFN), Stockholm, Sweden

2 Centre for Discrimination and Integration Studies, Linnaeus University, Växjö, Sweden 


\section{Introduction}

The two most important forms of non-standard employment in Sweden are fixedterm and part-time employment, jointly accounting for about $27 \%$ of employment in 2015. Since the late 1980s, fixed-term employment has become relatively more prevalent, while the opposite is true for part-time work. Recent decades have witnessed a sharp decline in the stringency of regulation of fixed-term contracts, while the regulation of permanent employment has remained at an above-average level compared to OECD countries. According to the most recent OECD summary indicator of employment protection in 2013, Sweden now ranks among the countries with the largest gap in regulation between permanent and fixed-term jobs. ${ }^{1}$

Non-standard employment may be a concern because it represents weaker attachment to the labour market than regular work. To shed more light on this issue, this paper decomposes the employment rate of full-time workers on permanent contracts into various subcomponents, paying special attention to the labour market attachment of females and the foreign born. The most detailed analysis in the paper is devoted to fixed-term contracts. We first examine the transition probabilities to permanent contracts and relate the results to findings for other countries. We then analyze the wage disadvantage of having a fixed-term contract in a regression framework and ask ourselves whether this disadvantage is larger for those born abroad than for natives and to what extent the type of fixed-term contract matters for the estimated wage premia. This issue has received scant attention in the literature and, unlike previous studies, we make a distinction between different types of fixed-term contracts.

We do not explicitly consider other forms of non-standard employment than fixedterm and part-time work, mainly due to data limitations and the fact that relatively few workers are engaged in them. ${ }^{2}$ This is not to say that these other forms of non-standard employment may not grow in importance in the future.

The paper is organized as follows. The next section discusses the evolution of fixed-term and part-time work over time and the characteristics of the workers in these forms of employment. Section 3 presents the decomposition of the employment rate of full-time workers on permanent contracts. Section 4 contains the special analysis of fixed-term employment. Section 5 concludes the paper.

\section{Evolution of Non-standard Employment and Its Distribution}

Fixed-term employment in Sweden is regulated in the Employment Protection Act (EPA). The Act states that an open-ended contract should be the norm for employment relationships and defines, inter alia, the circumstances under which fixed-term contracts are allowed and their maximum duration. Five types of fixed-term contracts

\footnotetext{
1 http://www.oecd.org/els/emp/oecdindicatorsofemploymentprotection.htm.

2 Calmfors et al. (2018) provide an extensive analysis of self-employment, fixed-term employment, temporary agency work, employment in "umbrella companies" and black market work in Sweden.
} 


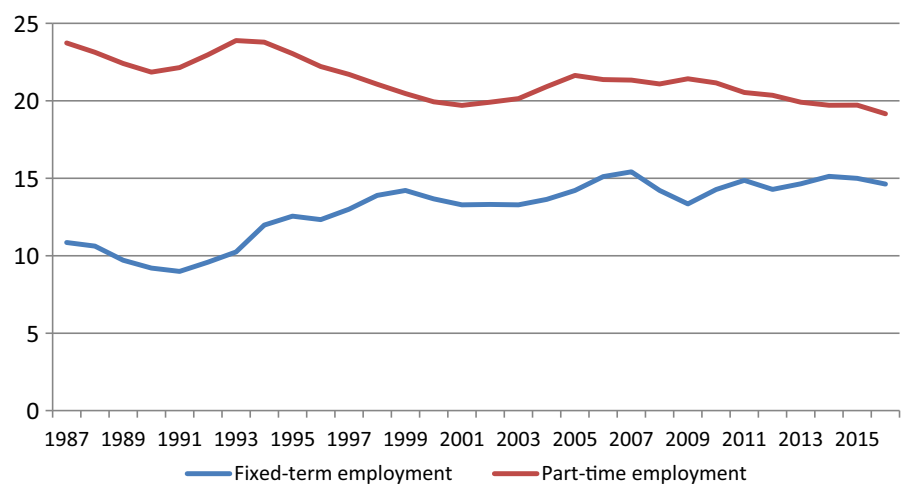

Fig. 1 Fixed-term and part-time employment. Per cent of total employment. Notes: Total employment includes employees and self-employed. Part-time employment is defined as regular work hours less than $35 \mathrm{~h}$ per week. Fixed-term employment refers to the age group 16-64, while part-time employment refers to those aged 20-64. Source: Own calculations based on aggregate data from the Labour Force Surveys

are mentioned in the legislation: seasonal work, replacement, probation, so-called General fixed-term employment and contracts for workers at least 67 years of age. (The various contract types are discussed in more detail in Sect. 4.2.) Part-time employment is not directly regulated by law, but may be influenced by the tax and social insurance systems.

Figure 1 shows the evolution of fixed-term and part-time employment over the period 1987-2016. Fixed-term employment increased from around 11\% of total employment in 1987 to around $15 \%$ in 2005 and has remained rather stable at that level.

What explains this pattern? Sweden experienced two deep economic downturns during the period covered by Fig. 1: one in the early 1990s-partially of domestic origin and the most severe one in terms of employment loss-and one in association with the Great Recession in 2008-2009. In addition, Sweden loosened regulation of fixedterm contracts considerably and on several occasions during the period (in 1993, 1997 and most drastically in 2007). ${ }^{3}$ But judging from the figure, the correlation with the incidence of fixed-term employment is rather weak. The fact that parts of employment protection legislation can be undone in collective agreements adds complexity to the issue. $^{4}$

Holmlund and Storrie (2002) argue that the increase in fixed-term unemployment up to the early noughties is best explained by changing macroeconomic conditions in the wake of the 1990s recession. Rising unemployment, albeit from a very low level, increased incentives among employers to offer fixed-term jobs and incentives among

\footnotetext{
3 See Skedinger (2008).

4 It is not uncommon that collective agreements deviate from the EPA regarding regulation of fixed-term employment. In such cases, the collectively agreed regulations tend to be more restrictive than those in the EPA (Calmfors et al. 2017).
} 
workers to accept them. ${ }^{5}$ It is of interest to make a comparison with the experiences of the other Nordic countries. Holmlund and Storrie (2002) note that a severe financial crisis occurred also in Finland in the early 1990s, with a similarly permanent rise in unemployment followed by an increase in fixed-term employment, but without any liberalization of its regulation. Denmark and Norway experienced more favourable macroeconomic conditions and saw no increase in fixed-term employment. The Great Recession was not associated with a permanent upward shift in the unemployment rate in Sweden, so the stability in fixed-term employment since then also seems consistent with the explanation offered by Holmlund and Storrie (2002), although this may not be the whole story.

Fixed-term employment is volatile and contributes strongly to variation in unemployment. According to Harbo Hansen and Malmberg (2016), inflow to and outflow from fixed-term employment accounted for $44 \%$ of the variation in the unemployment rate between 1987 and 2012. However, the patterns of employment adjustment were in important respects quite different in the two crises (Skedinger 2012). In the first one, it was mainly permanent jobs that were lost, while there was even a small increase in the number of fixed-term workers. This pattern was reversed in the Great Recession, with fixed-term employment accounting for two-thirds of job losses. As the stock of fixed-term workers increased, it is conceivable that employers learned over time how to adjust their workforce in the most flexible way.

Part-time employment decreased in tandem with the increase in fixed-term employment up to the early noughties and has since then remained at a stable level of around $20 \%$. The decline in part-time work is consistent with increasing incentives for fulltime work following the large reduction of marginal taxes in the early 1990s. Generous conditions for parental leave may also have reduced the supply of part-time work. Most part-timers work long part-time (20-34 h). Figure 2 reveals that it is long part-time that accounts for the decline in part-time employment, whereas the incidence of short part-time (1-19 h) increases modestly over time.

Table 1 shows the incidence of fixed-term and part-time employment in various demographic groups in 2015. As expected, these forms of non-standard employment are more common among females, the young (aged 15-24), the elderly (aged 65-74) and those with primary education. These groups are also more likely to be working short part-time if on a part-time contract. The picture for the foreign born is mixed. One the one hand they are clearly overrepresented among those in fixed-term employment, on the other hand they are on part-time to about the same extent as natives. Nor are the foreign born overrepresented among those working short part-time.

Calmfors et al. (2017) report that the young, the foreign born, the low educated and those with low proficiency levels are overrepresented in fixed-term jobs in Sweden to a larger extent than is the case in the other Nordic countries and in the EU in general.

\footnotetext{
5 This is obviously different from the typical cyclical response of fixed-term employment. In a downturn there is usually a decline in the share of fixed-term jobs as these workers are easier to lay off than permanent workers. In the beginning of the upturn there is sharp increase in fixed-term employment as employers are uncertain about the sustainability of the upturn. According to Holmlund (2009), adverse macroeconomic shocks caused the steep rise in unemployment in Sweden. These shocks were partially due to domestic policy failures - bad timing of financial liberalization and tax reform and long-lasting effects of monetary contraction in the early 1990 s.
} 


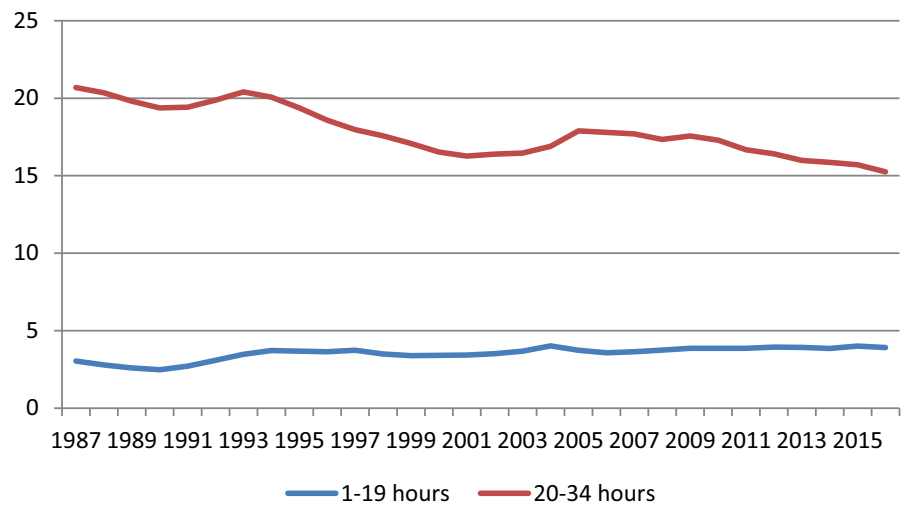

Fig. 2 Short and long part-time employment. Per cent of total employment. Notes: See Fig. 1. Source: Own calculations based on aggregate data from the Labour Force Surveys

Table 1 Fixed-term and part-time employment, 2015. Source: Own calculations based on data from the Labour Force Surveys

\begin{tabular}{lllll}
\hline Group & $\begin{array}{l}\text { Fixed-term } \\
\text { employment }\end{array}$ & \multicolumn{3}{l}{ Part-time employment } \\
\cline { 3 - 5 } & & $1-34 \mathrm{~h}$ & $1-19 \mathrm{~h}$ & $20-34 \mathrm{~h}$ \\
\hline All & 15.3 & 24.5 & 6.8 & 17.8 \\
Males & 13.3 & 15.7 & 5.4 & 10.3 \\
Females & 17.5 & 34.3 & 8.3 & 26.0 \\
Age 15-19 & 74.2 & 74.5 & 52.0 & 22.4 \\
Age 20-24 & 48.4 & 41.4 & 18.4 & 23.0 \\
Age 25-54 & 11.2 & 18.7 & 3.0 & 15.8 \\
Age 55-64 & 6.1 & 23.3 & 3.5 & 19.9 \\
Age 65-74 & 23.9 & 68.1 & 37.3 & 30.8 \\
Natives & 14.2 & 24.4 & 6.8 & 17.6 \\
Foreign born & 20.8 & 25.3 & 6.4 & 18.8 \\
Primary education & 28.1 & 37.3 & 17.5 & 19.8 \\
Secondary education & 14.3 & 24.4 & 5.2 & 19.2 \\
Tertiary education & 13.6 & 22.0 & 5.9 & 16.1 \\
\hline
\end{tabular}

Per cent of total employment for 15-74-year-olds

According to Calmfors et al. (2017), more liberal regulation of fixed-term contracts and lower wage dispersion are both associated with larger overrepresentation of marginal groups in fixed-term jobs. High wage floors may prevent employers from adjusting wages downwards as a compensation for offering permanent instead of fixed-term contracts to "wild cards" with little previous work experience, the hiring of whom is associated with greater risk for employers.

Given the overrepresentation of both females and the foreign born in fixed-term employment and of females in part-time employment it is of interest to examine labour 
market outcomes associated with these forms of employment by gender and place of birth in more detail. This is done in Sects. 3 and 4.

\section{Non-standard Employment and Attachment to the Labour Market}

One reason why non-standard employment may be a concern is that it is associated with a weaker attachment to the labour market than regular employment. Although most, if not all, forms of non-standard employment are preferable to unemployment and may serve as springboards to regular jobs, it is nevertheless the case that non-standard employment represents weaker attachment than regular work. ${ }^{6}$

This section, which draws on Calmfors et al. (2017), attempts to measure the degree of labour market attachment, taking into account various forms of non-standard employment and examining the extent to which these jobs contribute to weaker attachment among males, females and the foreign born depending on length of residence in Sweden. Another possible gauge of labour market attachment is annual earnings, which also could be decomposed by type of employment. The focus on employment in this section is motivated by the wide gap in employment rates between natives and foreign born in Sweden, whereas the corresponding gap in earnings is much smaller (as illustrated in Sect. 4.2).

Attachment to the labour market is defined by the permanent full-time employment rate, i.e., the number of full-time workers on permanent contracts relative to the population. This measure can be decomposed as follows:

$\frac{\begin{array}{c}\text { Permanent full-time } \\ \text { employment }\end{array}}{\text { Population }}=\frac{\begin{array}{c}\text { Permanent full-time } \\ \text { employment }\end{array}}{\text { Permanent employment }} \times \frac{\begin{array}{c}\text { Permanent } \\ \text { employment }\end{array}}{\text { Employment }} \times \frac{\text { Employment }}{\text { Population }}$,

where the first term on the right-hand side of Eq. (1) is the share of full-time workers among those on permanent contracts, the second term is the share of workers who are permanently employed and the third term is the employment rate. ${ }^{7}$ Total employment consists of employees and those in self-employment and for simplicity the latter are assumed to be on "permanent contracts", although the distinction by contract type is not relevant for the self-employed. Another simplifying assumption is that selfemployment, like regular employment, represents a high degree of attachment to the labour market. This is not necessarily the case, as self-employment may be driven

\footnotetext{
6 It should be noted this conclusion does not rule out that non-standard employment may also reflect the preferences of workers. As a case in point, part-time employment is to a large extent voluntary.

7 Other measures of the degree of labour market attachment in Calmfors et al. (2017) decompose attachment also into the rate of employment in non-subsidized jobs. Available data do not allow calculating this component by length of residence. Jobs with employment subsidies from the Public Employment Service are of limited duration and always on a fixed-term contract.
} 
by necessity rather than opportunity, especially among the foreign born. ${ }^{8}$ Full-time employment is defined as a regular working time of at least $35 \mathrm{~h}$ per week.

Table 2 shows the attachment to the labour market in 2015, calculated according to Eq. (1), by gender, place of birth-Sweden, Other Europe, Asia and Africa-and length of residence for non-natives. The table is based on data from the Labour Force Surveys (Arbetskraftsundersökningarna), which have been linked to information on length of residence from register data.

For male natives, in the upper panel, the degree of overall attachment to the labour market is relatively strong, $69 \%$. This is mainly attributable to a large share of permanently employed working full time $(91 \%)$ and a high prevalence of permanent contracts among the employed $(90 \%)$, and to a somewhat lesser extent to the employment rate $(85 \%)$. The picture is quite different for those born abroad. For non-native males with a length of residence up to 5 years, labour market attachment is especially weak among the African born (13\%) and the Asian born (23\%). The weak attachment is mainly explained by relatively low employment rates (42 and 49\%, respectively) and few workers with permanent contracts (43 and 53\%, respectively). The fact that many recent arrivals among the employed have fixed-term contracts is not surprising, as this is common also for native new entrants in the labour market (as evidenced in Table 1). What is more disturbing is that labour market attachment, although improving over time, remains quite far behind that of natives even after more than 10 years of residence in Sweden, except for the European born. The degree of attachment is 54\% for those of African origin and 51\% for the Asian born. It is chiefly relatively lower employment rates, but also lower prevalence of permanent contracts that contribute to explaining why these groups continue to lag behind natives. The rate of full-time work among the employed is close to that of natives.

The corresponding figures for females are shown in the lower panel of Table 2. Labour market attachment is consistently weaker than among males, for both natives and those born abroad. Native females exhibit an overall degree of attachment of $51 \%$. Among non-natives with the shortest length of residence, the degree of attachment is merely 3\% for the African born and 7\% for the Asian born. Low employment rates provide most of the explanation, but the fact that fewer workers have permanent contracts and full-time jobs also plays a role. After at least 10 years of residence, the degree of attachment rises but is still at low levels (34 and 39\%, respectively).

Table 2 accounts for work hours in a rather crude way, as it only distinguishes between full-time and part-time employment. It can be argued that short part-time (less than $20 \mathrm{~h}$ per week), represents a lower degree of labour market attachment than long part-time. Table 3 calculates the employment rate in full-time equivalents for the same groups as in the previous table. We adjust the employment rate by multiplying it with average regular work hours divided by 35 for part-timers and multiplying it with 1 for full-timers, as a weighted average. Comparing the regular employment rates in the right-most column of Table 2 with the hours-adjusted rates in Table 3, we note

\footnotetext{
8 Assuming that self-employment is equivalent to being on a fixed-term contract reduces the degree of labour market attachment compared to Table 2, as shown in an online appendix on the homepage of the Swedish Labour Policy Council (http://www.arbetsmarknadsekonomiskaradet.se/publicerat/, scroll down to “Tekniskt appendix till 'Tudelningarna på arbetsmarknaden'”, see Table A.1).
} 


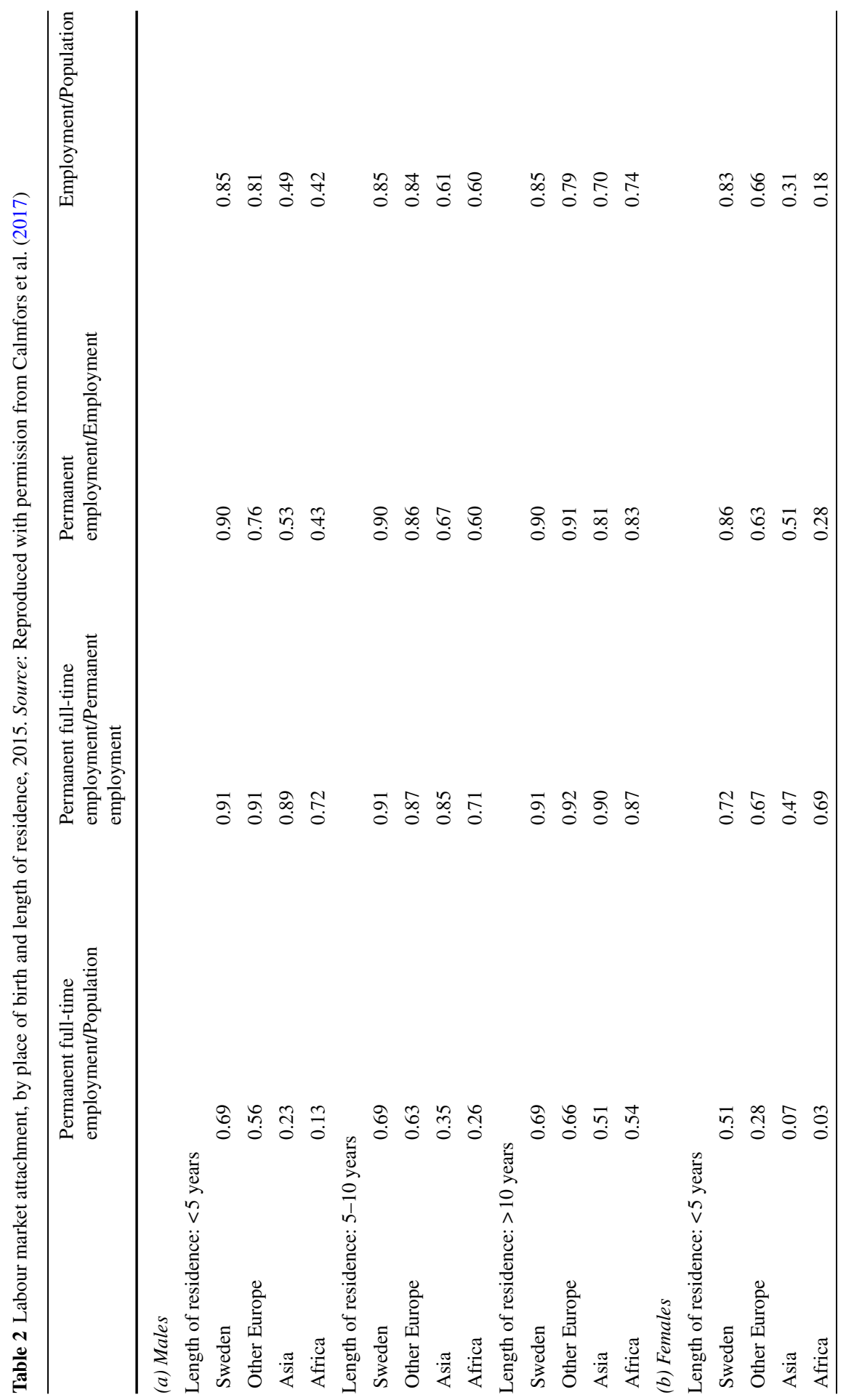




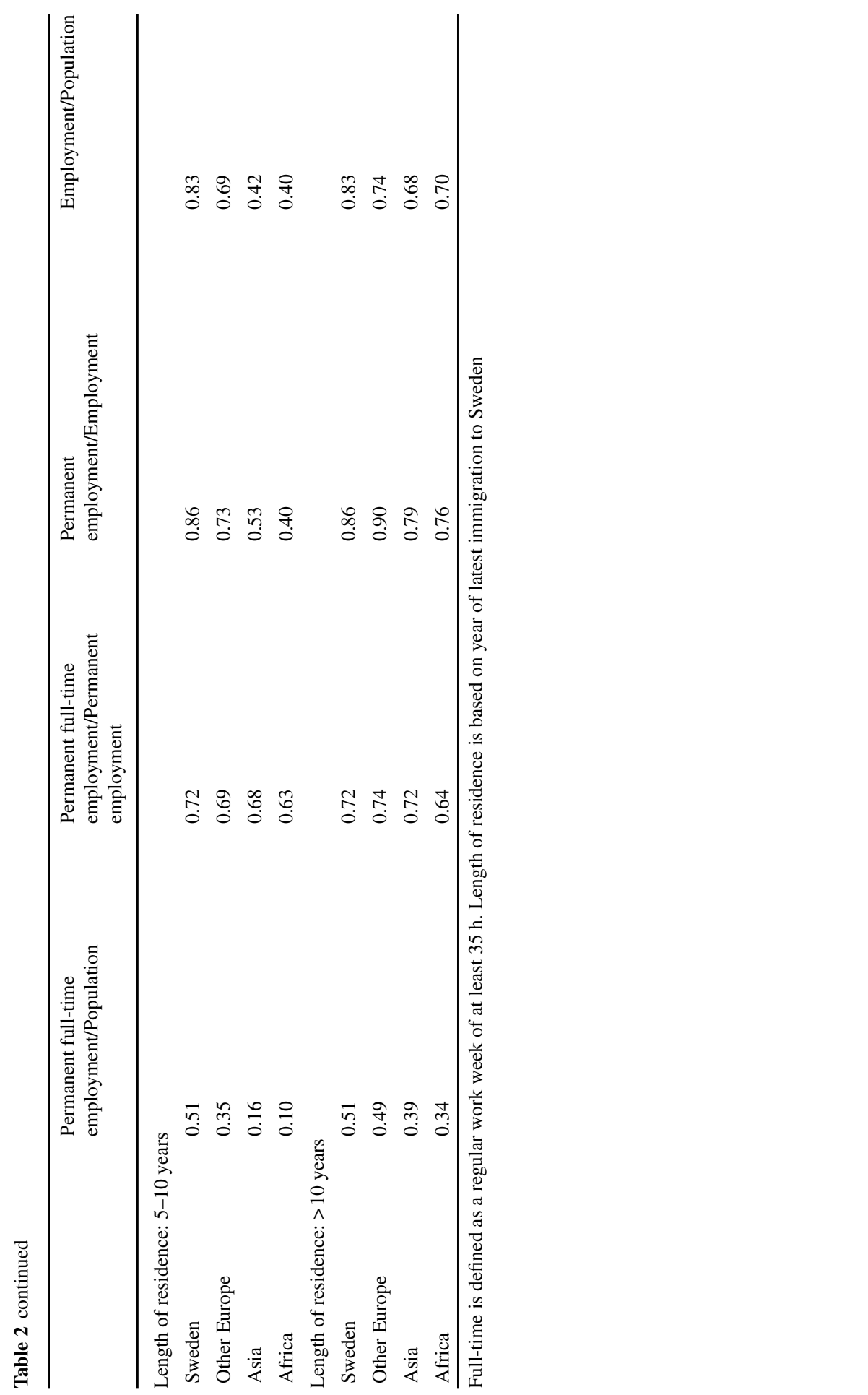


Table 3 Employment rate in full-time equivalents, by place of birth and length of residence, 2015. Source: Own calculations based on linked data from the Labour Force Surveys and the Population Register (length of residence)

\begin{tabular}{lcc}
\hline Length of residence & Males & Females \\
\hline$<5$ years & & \\
Sweden & 0.81 & 0.76 \\
Other Europe & 0.77 & 0.57 \\
Asia & 0.45 & 0.24 \\
Africa & 0.36 & 0.14 \\
$5-10$ years & & \\
Sweden & 0.81 & 0.76 \\
Other Europe & 0.80 & 0.61 \\
Asia & 0.56 & 0.35 \\
Africa & 0.52 & 0.34 \\
$>10$ years & & \\
Sweden & 0.81 & 0.76 \\
Other Europe & 0.76 & 0.68 \\
Asia & 0.66 & 0.62 \\
Africa & 0.70 & 0.63 \\
\hline
\end{tabular}

The full-time equivalent employment rate is calculated as the weighted average of the employment rate for part-timers (multiplied by the average regular number of work hours per week divided by 35) and the employment rate for full-timers (multiplied by 1 ). See also notes to Table 2

that the gap between the two is in most cases larger for females than for males. For natives, for example, the difference is 7 percentage points for females while only 4 for males. Those of African origin with residence up to 10 years are an exception, for which the gap is larger among males than for females. However, the relation between natives and foreign born is not much affected by the hours-adjusted measure. This is consistent with Table 1, which showed that those born abroad are not overrepresented among workers with short part-time employment. Thus employment rates unadjusted for work hours overestimate the labour market attachment of females relative to that of males, but not for the foreign born relative to natives.

\section{A Closer Look at Fixed-Term Employment}

We noted in Sect. 3 that fixed-term employment contributes to weak labour market attachment among foreign born, and especially so for those with a short length of residence in Sweden. However, if fixed-term jobs act as springboards to permanent employment there is less cause for concern than if people go back and forth between fixed-term employment and unemployment. In this section, we complement the previous analysis of stocks by looking at flows as we examine the transition probabilities from fixed-term employment to other labour market states for natives and foreign born. We also consider the wage premium for fixed-term jobs in a regression framework and 
ask ourselves whether this premium differs depending on gender, place of birth and contract type.

\subsection{Transition Probabilities}

There is a large literature examining the stepping-stone hypothesis for workers in fixedterm employment, i.e., whether such contracts lead to permanent jobs or increased segmentation as workers go back and forth between temporary jobs and unemployment. Several empirical studies give support to the stepping-stone hypothesis. ${ }^{9}$ These studies typically rely on aggregates of several types of fixed-term contracts or confine themselves to one or two contract types. ${ }^{10}$ This is a serious limitation given the heterogeneity of fixed-term contracts, with quite different purposes and job characteristics. Another gap in the literature concerns the foreign born. To what extent the stepping-stone hypothesis applies to this particular group has received but scant attention, despite the overrepresentation in fixed-term jobs in most advanced countries.

To begin with, this section presents data on raw transition probabilities, i.e., unadjusted for individual characteristics, from aggregate fixed-term employment in Sweden. We then proceed to discuss recent econometric evidence on transition probabilities from various types of fixed-term contracts and unemployment to permanent employment, for both natives and the foreign born.

Figure 3 displays transition probabilities from fixed-term employment over different time horizons - one quarter, four quarters and seven quarters. The data have been collected from the Labour Force Surveys. Although the probabilities of leaving fixedterm for permanent employment increase the longer the time horizon, they are lower for people born outside Europe than for natives, while the probabilities of becoming unemployed are higher. In 2015, for example, the probability of having transited to permanent employment after seven quarters was $37.6 \%$ for people born outside Europe compared to $44.6 \%$ for natives.

Transition probabilities from fixed-term employment after four quarters for those born outside Europe by length of residence are presented in Fig. 4. Transitions to permanent employment increase with longer residence, but this is most apparent only after a very long period, around 20 years or more. It takes 11 years for people of non-European origin to achieve the average level of transition probabilities applying to natives over the period 2005-2016 (32\%).

In line with many previous studies, Calmfors et al. (2018) find support for the stepping-stone hypothesis, also after controlling for individual characteristics (includ-

\footnotetext{
9 See, e.g, Berton et al. (2011) and Ichino et al. (2008) for studies on Italy, Booth et al. (2002) for the UK, Givord and Wilner (2015) for France, Hartman et al. (2010) for Sweden and OECD (2015) for an analysis of $17 \mathrm{OECD}$ countries. The latter finds evidence for the stepping-stone hypothesis for all countries examined except France and Korea. However, Ichino et al. (2008) and Givord and Wilner (2015) argue that temporary agency work acts as a stepping stone to permanent jobs to a lesser extent than fixed-term contracts in general. Autor and Houseman (2010) reach a similar conclusion for temporary agency work in the US.

10 Berglund et al. (2017), Håkansson (2001) and Wallette (2004) are exceptions. Using detailed Swedish data on contract types, they all find evidence on strongly heterogeneous effects on transition probabilities from fixed-term to permanent employment.
} 
(a) Natives
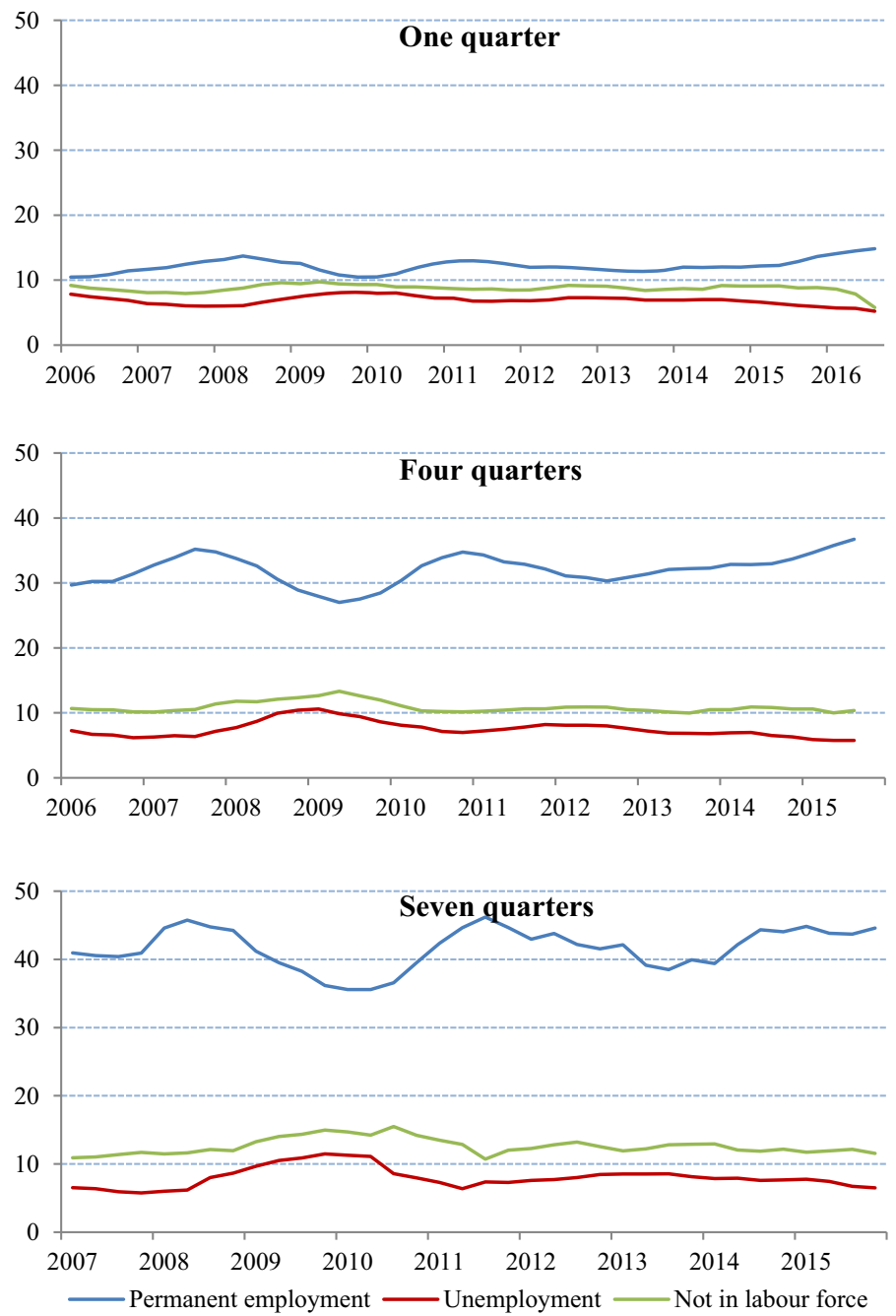

Fig. 3 Transition probabilities from fixed-term employment to other labour market states (\%). Notes: The data refer to persons aged 20-64 and are moving averages over four quarters. Labour market states are observed during a reference week at two points in time (quarters). For all time horizons, individuals may have been in other states in the period between observations than the one finally observed. All differences in transition probabilities between natives and those born outside Europe (except for the difference for not in the labour force after seven quarters) are statistically significant at the 5\% level. Source: Reproduced with permission from Calmfors et al. (2017)

ing labour market histories, proxied by earned income in previous years). But those born outside of Europe are less likely than natives to transit from fixed-term contracts and unemployment to permanent jobs, The results also suggest that fixed-term contracts are relatively more important as stepping-stones to permanent positions for the 
(b) Born outside Europe
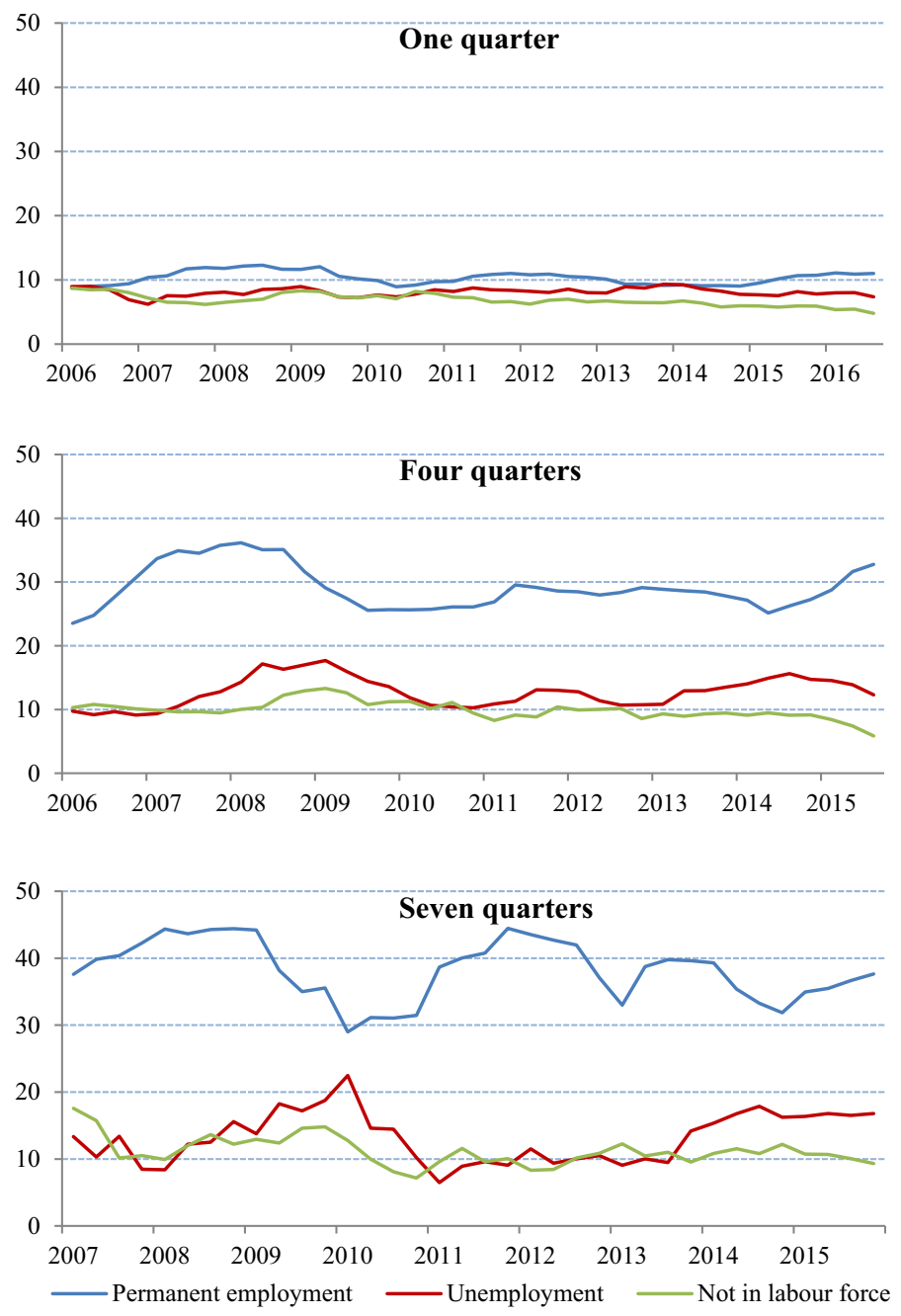

Fig. 3 continued

non-European born than for natives, if one compares with the transition probabilities from unemployment in the respective groups. This applies to all types of fixed-term contracts, except probation (for which the likelihood to exit to open-ended contracts is high already for both natives and those born outside of Europe).

\subsection{Econometric Analysis of the Wage Premium for Fixed-Term Employment}

Fixed-term employment is not only more insecure than permanent employment, but may also be associated with a different wage level on average. A thorough analysis 


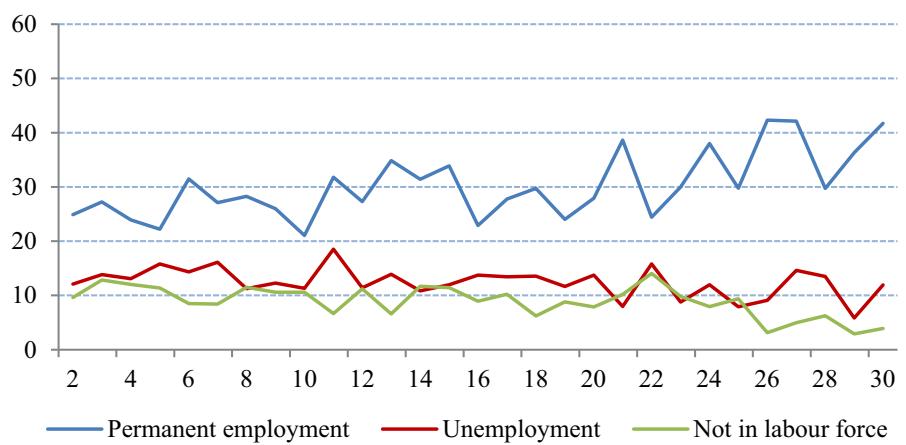

Fig. 4 Transition probabilities from fixed-term employment to other labour market states for persons born outside Europe, by length of residence (\%). Notes: Averages over the period 2005-2016 with a time horizon of four quarters. The horizontal axis shows length of residence in years, which is based on latest year of immigration to Sweden. Source: Reproduced with permission from Calmfors et al. (2017)

of the welfare consequences of fixed-term jobs requires that the wage dimension is accounted for. It is of interest to examine the raw wage differentials associated with fixed-term employment relative to permanent employment, as well as the wage premia, i.e., given individual characteristics. The prediction from economic theory is ambiguous. On the one hand, the insecurity associated with fixed-term employment on part of the employee could imply a compensating wage differential, i.e., a positive wage premium. On the other hand, fixed-term contracts are likely to be associated with less training than permanent jobs and less bargaining power, resulting in a negative wage premium.

Most of the empirical evidence indicates that the latter effects dominate, implying that fixed-term employees are paid less than their colleagues with permanent contracts. For example, OECD (2015) estimates a negative hourly wage premium in Germany, Korea and the UK of 6-8\% for males and 8-10\% for females. For Australia, however, the wage premium turns out to be zero. Booth et al. (2002) report wage premia for the UK of similar magnitude to those in OECD (2015). A cross-country analysis by Kahn (2016) finds that the negative hourly wage premia are larger for foreign born than for natives, implying that those born abroad gain relatively more from transiting to a permanent contract. ${ }^{11}$ All of the above studies control for observed individual heterogeneity and unobserved time-invariant heterogeneity. A related study for Sweden and Norway examines the long-term probabilities of low earnings, defined as having less than $50 \%$ of median earnings 5 years later (Svalund and Berglund 2018). The differences in the probabilities of low earnings between those initially on fixedterm contracts and in permanent jobs turn out to be modest for Sweden and even smaller for Norway (2-5 and 1-2 percentage points, respectively). None of the above studies makes a distinction between types of fixed-term contracts and only Kahn (2016) analyzes differences between natives and foreign born.

Our empirical approach is to use longitudinal data and successively add various individual characteristics to the specification, with the final one controlling also for

11 The sample includes Belgium, Denmark, France, Ireland, Portugal and Spain. 
unobserved individual heterogeneity that does not vary over time. Individual data on labour market status, place of birth, gender, education, age, tenure, region, occupation, industry, and establishment size have been collected from the Labour Force Surveys. The data have been linked to information on monthly wages (in full-time equivalents) from the Wage and Salary Structure Statistics (Lönestrukturstatistiken) as well as information on length of residence for the foreign born from the Population Register (Registret över totalbefolkningen).

Because the wage data are taken from employers' payroll records they should be measured with minimal error. These data are collected by sector-central government, local government and private business - and wages are observed once a year. All employers in the public sector are included and so are all firms with at least 500 employees in the private sector, but smaller firms in this sector are sampled. The period of measurement is September in central government and the private sector and November in local government. The annual wage data have been matched with the corresponding quarter, depending on sector, in the Labour Force Surveys (we will later check the robustness of the results to the specifics of this matching procedure). For individuals with more than one job, the data refer to the main job, with the highest wage. The construction of the data set makes it possible to observe some individuals in two consecutive years, but individuals with just one observation are also included. Finally, the data were trimmed according to procedures commonly used in the empirical literature. ${ }^{12}$

Table 4 shows the raw wage differentials for fixed-term relative to permanent employment, based on all matched observations in the data set (adjusted only for year and sector due to the differing sampling procedures). The differentials refer to fixed-term employment in general, as an average over the period 2005-2015, as well as five specific contract types, namely replacement contracts (the most common type), probation, General fixed-term employment (allmän visstidsanställning), introduced in July of 2007, on-call contracts and other contracts, which include seasonal and project work. ${ }^{13}$ The maximum period allowed for replacement and General fixed-term contracts are 2 years and for probation it is 6 months. In addition, General fixed-term employment can be used without any specific reasons, making it the most flexible form of contract. On-call contracts are characterized by short employment spells, in many cases repeated at the same employer. The wage differentials by fixed-term contract type have been calculated for the period 2008-2015, since there are no observations for general fixed-term employment in the data in 2007.

The wage differentials in Table 4 are calculated within the respective demographic groups, so the figure for, e.g., foreign-born males is the estimated wage differential

\footnotetext{
12 Observations fulfilling any of the following criteria were excluded from the linked sample: Below 20 years or above 64 years of age; self-employed; on a fixed-term contract but with permanent contract in regular job; regular work hours above 168 per month; negative tenure (due to reporting error); wage in the lowest or highest percentile (outliers). These exclusions resulted in a loss of observations of $3.7 \%$ for males and $4.9 \%$ for females. Missing values on explanatory variables in the regressions resulted in a further loss of observations of $2.5 \%$ for both males and females.

13 Replacement contracts account for $33.4 \%$ of fixed-term contracts in the sample, followed by on-call (30.0), probation (7.5), General fixed-term (4.9) and other contracts (24.2). Note that the contract types in the Labour Force Surveys do not correspond exactly to the types defined in the EPA (see Sect. 2).
} 


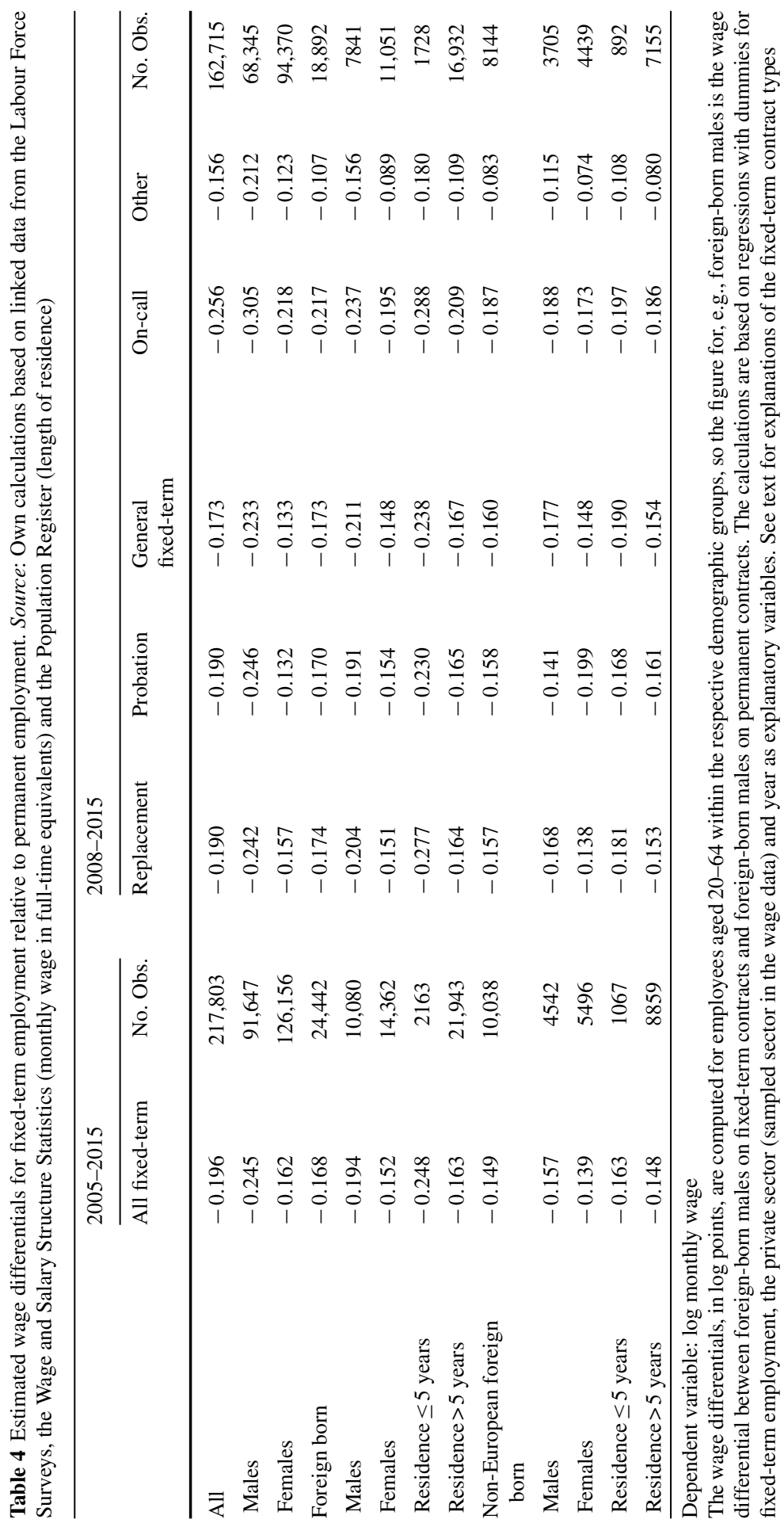


between foreign-born males on fixed-term contracts and foreign-born males on permanent contracts. Due to the construction of the data set, with all employees in the public sector included, but sampling of private firms, there are more observations on females than on males. As expected, the wage differentials are all negative but there is a great deal of variation in magnitude depending on gender, place of birth, length of residence and contract type. On average, workers on fixed-term contracts are paid $17.8 \%$ less than those permanently employed. ${ }^{14}$ The differential is larger for males $(-21.7 \%)$ than for females $(-15.0 \%)$ and smaller for the foreign born, especially non-Europeans $(-13.8 \%)$, than for natives. The foreign born with length of residence up to 5 years exhibit smaller differentials than those who have stayed longer in Sweden. On-call contracts are in almost all cases associated with the largest wage differentials (ranging from -15.9 to $-26.3 \%$ depending on demographic group), while "other contracts" rather consistently come up with the smallest ones $(-7.1$ to $-19.1 \%)$.

We now turn to a more elaborative econometric analysis of the wage differentials, accounting for individual heterogeneity. In Table 5, three different specifications are estimated, in which more controls are added successively. All specifications are estimated separately for males and females and include a dummy for fixed-term employment and interactions between this variable and place of birth. The basic model also controls for exogenous worker characteristics-age, age squared, place of birth-as well as year. The extended model adds several worker and firm characteristics as well as a business cycle indicator: tenure (in months), tenure squared, five education dummies, nine occupation dummies, four sector dummies, seven establishment size dummies and the regional unemployment rate. The final model controls also for unobserved, individual fixed effects and includes all previous variables that may vary over time (i.e., not place of birth). In effect, this model estimates the wage premia only for those who transit between fixed-term and permanent employment.

To save space, Table 5 reports estimates only for the variables of main interest, namely fixed-term employment, place of birth and interactions between the two. ${ }^{15}$ Adding more controls reduces the estimated wage premia for fixed-term jobs drastically; for male natives, the differential in the basic model, $-16.2 \%$, shrinks to $-9.9 \%$ in the extended model and ultimately to $-2.8 \%$ when unobserved, time-invariant individual characteristics are taken into account. A similar pattern emerges for female natives, with a reduction from a differential of $-11.0 \%$ in the basic model to $-1.7 \%$ in the fixed effects model. These final estimates are well below those reported by OECD (2015) for other countries.

Unsurprisingly, the foreign born on permanent contracts, and especially those from non-European countries, tend to earn lower overall wages than natives on permanent contracts. In the extended model, the estimates indicate that foreign-born males are paid $2.3 \%$ less than natives while the corresponding figure for those born outside

\footnotetext{
14 Since the dependent variable is log-normal and the independent variable is a dummy, an interpretation in terms of percentages requires the transformation $\left[\mathrm{e}^{\beta}-1\right] \times 100$, where $\beta$ is the coefficient of the dummy.

15 Full regression results are available from the author on request. Basically all of the unreported variables work according to expectation. Thus both age and tenure are associated with higher wages at a decreasing rate and wages increase with higher education. Higher regional unemployment reduces wages, while establishment size has a positive effect. As fixed effects are introduced, most coefficients of these variables are rendered insignificant.
} 


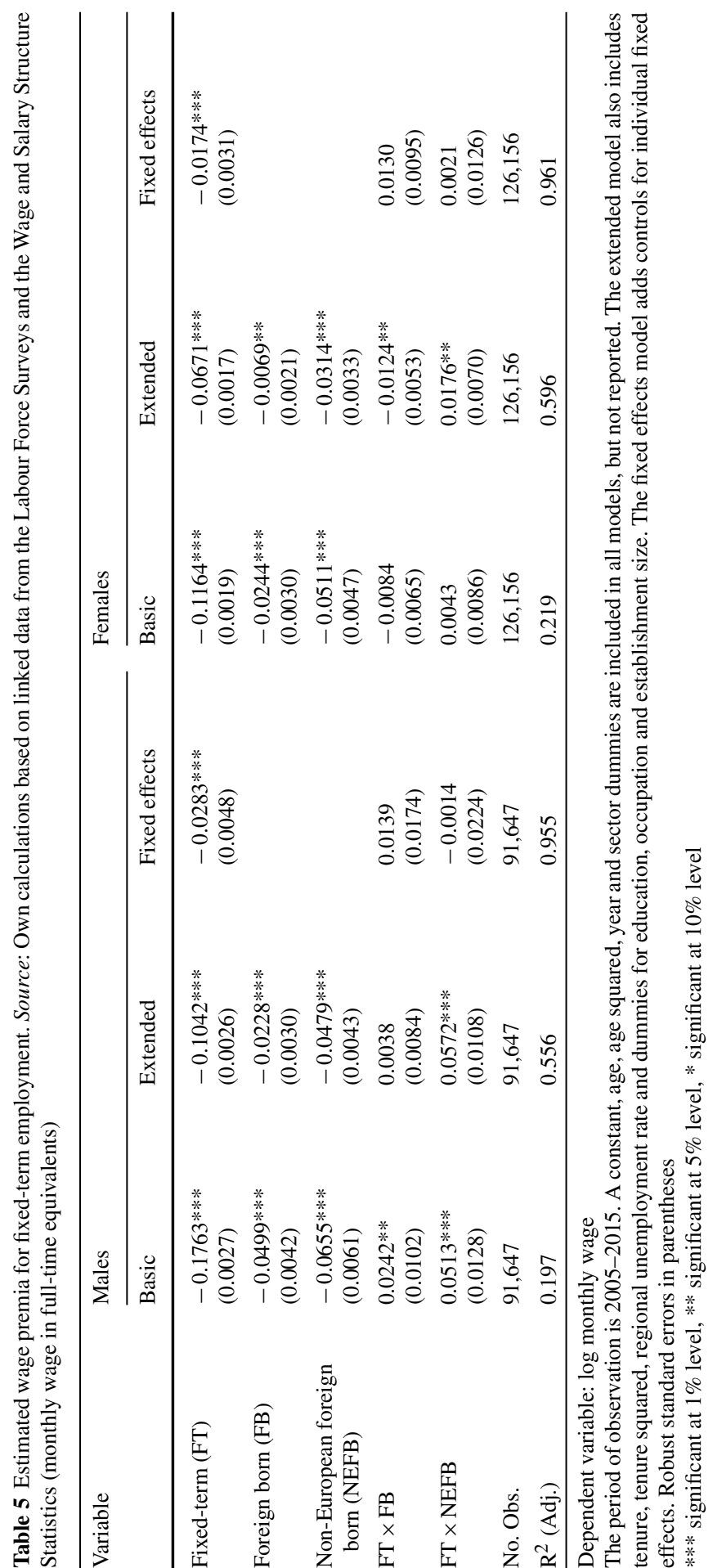


Europe is $6.8 \%$. In contrast to Kahn (2016), it turns out that the wage disadvantage of having a fixed-term contract is not very different for the foreign born versus natives. All estimates of the interacted variables are insignificant in the fixed effects model, for both males and females.

We now proceed to examine the wage premia conditional on type of fixed-term contract. According to Table 6, there is little variation in these premia, once individual fixed effects are controlled for. Probation stands out as it is not associated with a negative premium, which is consistent with the fact that these contracts tend to be transformed to permanent ones with the same employer. "Other contracts" are associated with a negative wage premium of 3-4\%, including all controls. The interactions show that, on the whole, the type of contract does not matter much for difference in wage premia between natives and foreign born. ${ }^{16}$ An exception is General fixed-term employment, for which there is a positive wage premium for males born abroad relative to natives, amounting to $9.9 \%$. This wage advantage pertains entirely to those born within Europe (as the wage premium for those born outside Europe is close to the one for natives).

The finding that the negative wage premium for fixed-term jobs is small in Sweden is robust to several robustness and heterogeneity checks, as evident in the fixed effects regressions in Table 7. First, the Labour Force Survey data and the wage data were matched by month, instead of by quarter, to minimize the risk for measurement errors due to mismatches. We went on to add a control for industry, which is possible to do only for the period 2008-2015 due to changes in the classification of industries. Then we included full-timers only in the sample. Finally, we looked at private small firms separately, as these are underrepresented in the sample and may differ in important respects from other workplaces. These checks resulted in a substantial loss of observations in some cases, but did not change the conclusions from those in Table 5.

Despite the robustness of the fixed effects regressions, a few caveats are in place. If the explanatory variables are measured with error, biases in the estimates will be exacerbated with fixed effects. The type of fixed-term contract is probably more likely to be misreported than the state of being on any such contract, implying that the regressions by contract type should be viewed with more caution than the regressions that do not make this distinction. Another caveat with the fixed effects regressions is that those workers who transit between fixed-term and permanent jobs may be a very selective group that differs in important respects from those who do not make the transition. Those who find permanent employment may be more productive than other workers on fixed-term contracts and those who go from a permanent job to fixed-term employment may only do so because of a dismissal or a benefit in the form of, e.g., a higher wage. However, unless such selection affects natives and foreign born in systematically different ways, the estimated differences in wage premia between the two groups will not be affected.

\footnotetext{
16 F-tests reveal that the coefficients of the interacted variables are insignificant at the $10 \%$ level in the regressions with fixed effects in Table 6.
} 
Table 6 Estimated wage premia for fixed-term employment with fixed-term contract type. Source: See Table 5

\begin{tabular}{|c|c|c|c|c|c|c|}
\hline \multirow[t]{2}{*}{ Variable } & \multicolumn{3}{|l|}{ Males } & \multicolumn{3}{|l|}{ Females } \\
\hline & Basic & Extended & Fixed effects & Basic & Extended & Fixed effects \\
\hline $\begin{array}{l}\text { Replacement } \\
\text { (R) }\end{array}$ & $\begin{array}{l}-0.1785^{* * * *} \\
(0.0056)\end{array}$ & $\begin{array}{l}-0.0991 * * * \\
(0.0052)\end{array}$ & $\begin{array}{l}-0.0304 * * * \\
(0.0090)\end{array}$ & $\begin{array}{l}-0.1179 * * * \\
(0.0030)\end{array}$ & $\begin{array}{l}-0.0716^{* * * *} \\
(0.0027)\end{array}$ & $\begin{array}{l}-0.0150 * * * \\
(0.0044)\end{array}$ \\
\hline $\begin{array}{l}\text { Probation } \\
\text { (P) }\end{array}$ & $\begin{array}{l}-0.1517 * * * \\
(0.0081)\end{array}$ & $\begin{array}{l}-0.0818 * * * \\
(0.0074)\end{array}$ & $\begin{array}{l}-0.0071 \\
(0.0118)\end{array}$ & $\begin{array}{l}-0.0552 * * * \\
(0.0087)\end{array}$ & $\begin{array}{l}-0.0551 * * * \\
(0.0076)\end{array}$ & $\begin{array}{l}0.0048 \\
(0.0091)\end{array}$ \\
\hline $\begin{array}{l}\text { General } \\
\text { fixed-term } \\
\text { (G) }\end{array}$ & $\begin{array}{l}-0.1637 * * * \\
(0.0104)\end{array}$ & $\begin{array}{l}-0.0899 * * * \\
(0.0088)\end{array}$ & $\begin{array}{l}-0.0290 * * \\
(0.0137)\end{array}$ & $\begin{array}{l}-0.0958 * * * \\
(0.0084)\end{array}$ & $\begin{array}{l}-0.0863 * * * \\
(0.0068)\end{array}$ & $\begin{array}{l}-0.0248 * * \\
(0.0105)\end{array}$ \\
\hline $\begin{array}{c}\text { On-call } \\
(\mathrm{OC})\end{array}$ & $\begin{array}{l}-0.2049 * * * \\
(0.0051)\end{array}$ & $\begin{array}{l}-0.0704 * * * \\
(0.0054)\end{array}$ & $\begin{array}{l}-0.0235^{* * *} \\
(0.0116)\end{array}$ & $\begin{array}{l}-0.1543 * * * \\
(0.0033)\end{array}$ & $\begin{array}{l}-0.0379 * * * \\
(0.0033)\end{array}$ & $\begin{array}{l}-0.0171 * * \\
(0.0073)\end{array}$ \\
\hline Other $(\mathrm{O})$ & $\begin{array}{l}-0.1699 * * * \\
(0.0052)\end{array}$ & $\begin{array}{l}-0.1379 * * * \\
(0.0049)\end{array}$ & $\begin{array}{l}-0.0360 * * * \\
(0.0098)\end{array}$ & $\begin{array}{l}-0.0911^{* * * *} \\
(0.0047)\end{array}$ & $\begin{array}{l}-0.1058 * * * \\
(0.0040)\end{array}$ & $\begin{array}{l}-0.0321 * * * \\
(0.0081)\end{array}$ \\
\hline $\begin{array}{l}\text { Foreign born } \\
\quad(\mathrm{FB})\end{array}$ & $\begin{array}{l}-0.0482 * * * \\
(0.0050)\end{array}$ & $\begin{array}{l}-0.0205^{* * * *} \\
(0.0036)\end{array}$ & & $\begin{array}{l}-0.0246^{* * * *} \\
(0.0035)\end{array}$ & $\begin{array}{l}-0.0072 * * \\
(0.0025)\end{array}$ & \\
\hline $\begin{array}{l}\text { Non- } \\
\quad \text { European } \\
\text { foreign } \\
\text { born } \\
\text { (NEFB) }\end{array}$ & $\begin{array}{l}-0.0660 * * * \\
(0.0069)\end{array}$ & $\begin{array}{l}-0.0473^{* * * *} \\
(0.0049)\end{array}$ & & $\begin{array}{l}-0.0539 * * * \\
(0.0054)\end{array}$ & $\begin{array}{l}-0.0331 * * * \\
(0.0037)\end{array}$ & \\
\hline $\mathrm{R} \times \mathrm{FB}$ & $\begin{array}{l}0.0208 \\
(0.0248)\end{array}$ & $\begin{array}{l}0.0344 * * \\
(0.0174)\end{array}$ & $\begin{array}{l}0.0253 \\
(0.0270)\end{array}$ & $\begin{array}{l}-0.0090 \\
(0.0120)\end{array}$ & $\begin{array}{l}-0.0068 \\
(0.0093)\end{array}$ & $\begin{array}{l}0.0064 \\
(0.0141)\end{array}$ \\
\hline $\mathrm{P} \times \mathrm{FB}$ & $\begin{array}{l}-0.0176 \\
(0.0291)\end{array}$ & $\begin{array}{l}-0.0068 \\
(0.0239)\end{array}$ & $\begin{array}{l}-0.0145 \\
(0.0430)\end{array}$ & $\begin{array}{l}-0.0304 \\
(0.0293)\end{array}$ & $\begin{array}{l}-0.0145 \\
(0.0248)\end{array}$ & $\begin{array}{l}-0.0280 \\
(0.0217)\end{array}$ \\
\hline $\mathrm{G} \times \mathrm{FB}$ & $\begin{array}{l}-0.0327 \\
(0.0323)\end{array}$ & $\begin{array}{l}-0.0565^{* *} \\
(0.0276)\end{array}$ & $\begin{array}{l}0.0948 * * * \\
(0.0316)\end{array}$ & $\begin{array}{l}-0.0260 \\
(0.0311)\end{array}$ & $\begin{array}{l}-0.0275 \\
(0.0227)\end{array}$ & $\begin{array}{l}-0.0056 \\
(0.0276)\end{array}$ \\
\hline $\mathrm{OC} \times \mathrm{FB}$ & $\begin{array}{l}0.0019 \\
(0.0186)\end{array}$ & $\begin{array}{l}0.0320 * \\
(0.0170)\end{array}$ & $\begin{array}{l}0.0063 \\
(0.0432)\end{array}$ & $\begin{array}{l}-0.0209 * * \\
(0.0099)\end{array}$ & $\begin{array}{l}-0.0148 \\
(0.0091)\end{array}$ & $\begin{array}{l}0.0359 * \\
(0.0208)\end{array}$ \\
\hline $\mathrm{O} \times \mathrm{FB}$ & $\begin{array}{l}0.0383 * \\
(0.0201)\end{array}$ & $\begin{array}{l}-0.0127 \\
(0.0167)\end{array}$ & $\begin{array}{l}0.0153 \\
(0.0321)\end{array}$ & $\begin{array}{l}0.0235 \\
(0.0163)\end{array}$ & $\begin{array}{l}-0.0393 * * * \\
(0.0132)\end{array}$ & $\begin{array}{l}0.0232 \\
(0.0256)\end{array}$ \\
\hline $\mathrm{R} \times \mathrm{NEFB}$ & $\begin{array}{l}0.0327 \\
(0.0298)\end{array}$ & $\begin{array}{l}0.0113 \\
(0.0222)\end{array}$ & $\begin{array}{l}-0.0051 \\
(0.0408)\end{array}$ & $\begin{array}{l}-0.0013 \\
(0.0152)\end{array}$ & $\begin{array}{l}0.0188 \\
(0.0118)\end{array}$ & $\begin{array}{l}0.0117 \\
(0.0171)\end{array}$ \\
\hline $\mathrm{P} \times \mathrm{NEFB}$ & $\begin{array}{l}0.0871 * * \\
(0.0398)\end{array}$ & $\begin{array}{l}0.0649 * \\
(0.0337)\end{array}$ & $\begin{array}{l}-0.0405 \\
(0.0657)\end{array}$ & $\begin{array}{l}-0.0677^{*} \\
(0.0379)\end{array}$ & $\begin{array}{l}-0.0120 \\
(0.0295)\end{array}$ & $\begin{array}{l}0.0420 \\
(0.0386)\end{array}$ \\
\hline $\mathrm{G} \times \mathrm{NEFB}$ & $\begin{array}{l}0.0638 \\
(0.0406)\end{array}$ & $\begin{array}{l}0.0700 * \\
(0.0379)\end{array}$ & $\begin{array}{l}-0.1124^{* *} \\
(0.0465)\end{array}$ & $\begin{array}{l}-0.0177 \\
(0.0390)\end{array}$ & $\begin{array}{l}0.0047 \\
(0.0278)\end{array}$ & $\begin{array}{l}-0.0255 \\
(0.0366)\end{array}$ \\
\hline $\mathrm{OC} \times \mathrm{NEFB}$ & $\begin{array}{l}0.0811 * * * \\
(0.0217)\end{array}$ & $\begin{array}{l}0.0483 * * \\
(0.0202)\end{array}$ & $\begin{array}{l}0.0453 \\
(0.0527)\end{array}$ & $\begin{array}{l}0.0276 * * \\
(0.0124)\end{array}$ & $\begin{array}{l}0.0098 \\
(0.0114)\end{array}$ & $\begin{array}{l}-0.0204 \\
(0.0234)\end{array}$ \\
\hline $\mathrm{O} \times \mathrm{NEFB}$ & $\begin{array}{l}0.0675 * * * \\
(0.0246)\end{array}$ & $\begin{array}{l}0.0428 * * \\
(0.0203)\end{array}$ & $\begin{array}{l}0.0133 \\
(0.0431)\end{array}$ & $\begin{array}{l}0.0071 \\
(0.0214)\end{array}$ & $\begin{array}{l}0.0326 * \\
(0.0180)\end{array}$ & $\begin{array}{l}-0.0080 \\
(0.0291)\end{array}$ \\
\hline No. Obs. & 68,345 & 68,345 & 68,345 & 94,370 & 94,370 & 94,370 \\
\hline $\mathrm{R}^{2}$ (Adj.) & 0.169 & 0.539 & 0.955 & 0.161 & 0.561 & 0.961 \\
\hline
\end{tabular}

Dependent variable: $\log$ monthly wage

The period of observation is 2008-2015. See also notes to Table 5

$* * *$ significant at $1 \%$ level, ** significant at $5 \%$ level, * significant at $10 \%$ level 
Table 7 Robustness tests. Source: See Table 5

\begin{tabular}{|c|c|c|c|c|}
\hline \multirow[t]{2}{*}{ Regression } & \multicolumn{2}{|l|}{ Males } & \multicolumn{2}{|l|}{ Females } \\
\hline & Fixed effects & No. Obs. & Fixed effects & No. Obs. \\
\hline Table 5 & $\begin{array}{l}-0.0283^{* * * *} \\
(0.0049)\end{array}$ & 91,647 & $\begin{array}{l}-0.0174 * * * \\
(0.0031)\end{array}$ & 126,156 \\
\hline $\begin{array}{l}\text { Matching by } \\
\text { month }\end{array}$ & $\begin{array}{l}-0.0172 * * * \\
(0.0076)\end{array}$ & 30,611 & $\begin{array}{l}-0.0210 * * * \\
(0.0054)\end{array}$ & 42,448 \\
\hline $\begin{array}{l}\text { Controlling for } \\
\text { industry }\end{array}$ & $\begin{array}{l}-0.0252^{* * * *} \\
(0.0057)\end{array}$ & 68,254 & $\begin{array}{l}-0.0162^{* * *} \\
(0.0038)\end{array}$ & 94,274 \\
\hline Full-timers & $\begin{array}{l}-0.0306^{* * * *} \\
(0.0052)\end{array}$ & 82,074 & $\begin{array}{l}-0.0207^{* * *} \\
(0.0042)\end{array}$ & 83,997 \\
\hline Private small firms & $\begin{array}{l}-0.0311^{* * * *} \\
(0.0082)\end{array}$ & 43,899 & $\begin{array}{l}-0.0174 * * \\
(0.0086)\end{array}$ & 30,632 \\
\hline
\end{tabular}

Dependent variable: $\log$ monthly wage

The table reports the coefficient of fixed-term variable and the specifications correspond to the fixed-effects model in Table 5. The estimation period for the regressions controlling for industry is 2008-2015. The regressions for private small firms refer to private establishments with less than 500 employees. See also notes to Table 5

*** significant at $1 \%$ level, ** significant at $5 \%$ level, * significant at $10 \%$ level

\section{Conclusions}

In this paper, we have examined the two most prevalent forms of nonstandard employment in Sweden, fixed-term and part-time employment. We have argued that conventional employment statistics-not accounting for non-standard employment - provide an incomplete picture of the labour market attachment of various groups and particularly for females and those born in Africa and Asia. Their attachment is overestimated if only employment rates are considered.

We have presented a snapshot of various dimensions of labour market attachment at a particular point in time. To inform the policy debate, it should be useful to also be able to assess how the attachment to the labour market in various groups evolves over time, as, inter alia, the conditions in the labour market and the composition of immigrants change. This is a task probably best suited for a government agency, with resources to refine and improve the measures and update them on a regular basis. The more detailed analysis in the paper has dealt with fixed-term employment. Transition probabilities to permanent employment increase with the time horizon, but remain lower for the foreign born than for natives. Fixed-term employees earn less than those on permanent contracts, but the disadvantage seems to be smaller than in countries that have been examined elsewhere in the literature. Another finding is that there is no difference between foreign born and natives in the magnitude of these wage premia. The overall small wage premia may of course mask heterogeneous effects across the wage distribution. It is conceivable that the most low-paid workers on fixed-term contracts receive larger wage gains from a permanent job than other workers.

The small wage disadvantage of having a fixed-term job in Sweden is consistent with low wage dispersion compared to other countries, as documented by OECD 
(2016). High collectively agreed minimum wages may prevent downward adjustment of remuneration for the lowest paid employees. Wide coverage of collective bargaining and the absence of special regulations for fixed-term employees in collective agreements may also contribute to the small negative wage premia for fixed-term workers in Sweden.

Open Access This article is distributed under the terms of the Creative Commons Attribution 4.0 International License (http://creativecommons.org/licenses/by/4.0/), which permits unrestricted use, distribution, and reproduction in any medium, provided you give appropriate credit to the original author(s) and the source, provide a link to the Creative Commons license, and indicate if changes were made.

\section{References}

Autor, D., \& Houseman, S. (2010). Do temporary-help jobs improve labor market outcomes for low-skilled workers? Evidence from 'Work First'. American Economic Journal: Applied Economics, 2(3), 96-128.

Berglund, T., Håkansson, K., Isidorsson, T., \& Alfonsson, J. (2017). Temporary employment and the future labor market status. Nordic Journal of Working Life Studies, 7(2), 27-48.

Berton, F., Devicienti, F., \& Pacelli, L. (2011). Are temporary jobs a port of entry into permanent employment? International Journal of Manpower, 32(8), 879-899.

Booth, A. L., Francesconi, M., \& Frank, J. (2002). Temporary jobs: Stepping stones or dead ends? Economic Journal, 112(480), F189-F213.

Calmfors, L., Danielsson, P., Kolm, A.-S., Pekkarinen, T., \& Skedinger, P. (2017). Tudelningarna på arbetsmarknaden. Stockholm: Swedish Labour Policy Council.

Calmfors, L., Ek, S., Kolm, A.-S., Pekkarinen, T., \& Skedinger, P. (2018). Olika vägar till jobb. Stockholm: Swedish Labour Policy Council.

Givord, P., \& Wilner, L. (2015). When does the stepping-stone work? Fixed-term contracts versus temporary agency work in changing economic conditions. Journal of Applied Econometrics, 30(5), 787-805.

Håkansson, K. (2001). Språngbräda eller segmentering? En longitudinell studie av tidsbegränsat anställda. Forskningsrapport 2001:1, Institute for Labour Market Policy Evaluation, Uppsala.

Harbo Hansen, N.-J., \& Malmberg, H. (2016). Swedish unemployment dynamics. In Harbo Hansen, N.J. (Ed.), Jobs, unemployment and macroeconomic transmission. Ph.D. dissertation, Department of Economics, Stockholm University.

Hartman, L., Liljeberg, L., \& Nordström Skans, O. (2010). Stepping-stones, dead-ends or both? An analysis of Swedish replacement contracts. Empirical Economics, 38(3), 645-668.

Holmlund, B. (2009). The Swedish unemployment experience. Oxford Review of Economic Policy, 25(1), $109-125$.

Holmlund, B., \& Storrie, D. (2002). Temporary work in turbulent times: The Swedish experience. Economic Journal, 112(480), F245-F269.

Ichino, A., Mealli, F., \& Nannicini, T. (2008). From temporary help jobs to permanent employment: What can we learn from matching estimators and their sensitivity? Journal of Applied Econometrics, 23(3), 305-327.

Kahn, L. (2016). The structure of the permanent job wage premium: Evidence from Europe. Industrial Relations, 55(1), 149-178.

OECD. (2015). In it together: Why less inequality benefits all. Paris.

OECD. (2016). Employment outlook. Paris.

Skedinger, P. (2008). Effekter av anställningsskydd - vad säger forskningen? Stockholm: SNS Förlag.

Skedinger, P. (2012). Tudelad trygghet. In A. Teodorescu \& L.-O. Pettersson (Eds.), Jobben kommer och går - behovet av trygghet består. Ekerlids Förlag: Stockholm.

Svalund, J., \& Berglund, T. (2018). Fixed-term employment in Norway and Sweden: A pathway to labour market marginalization? European Journal of Industrial Relations. https://doi.org/10.1177/ 0959680117740777.

Wallette, M. (2004), Temporary jobs in Sweden: Incidence, exit, and on-the-job training, Lund Economic Studies no. 20, University of Lund. 